\title{
African superplume composition: insight from the Mozambique Margin
}

\author{
S. REVILLON $*^{1,2}$, V ROCHE $^{3}$, S LEROY $^{3}, \mathrm{~F}$ \\ GUILLOCHEAU ${ }^{4}$, G RUFFET ${ }^{4}$, D ASLANIAN ${ }^{5}, \mathrm{M}$ \\ MOULIN, ${ }^{5}$ M DALL'ASTA ${ }^{6}$, J.M KLUSKA $^{6}$
}

${ }^{1}$ SEDISOR Plouzané, France

${ }^{2}$ CNRS, Univ Brest, UMR 6538, Plouzané, France

${ }^{3}$ Sorbonne Université, CNRS, ISTeP, Paris, France,

${ }^{4}$ Univ. Rennes 1, Geosciences Rennes, Rennes, France

${ }^{5}$ IFREMER, Géosciences Marine, Plouzané, France

${ }^{6}$ TOTAL Exploration and Production, Pau, France

The Karoo Large Igneous Province is one of the most extensively studied continental trapp [1, 2 and reference therein]. Nonetheless the nature, composition and origin of some parts of this province, and principally its youngest portions outcropping within the Lebombo province remain unclear [3]. Moreover the relationships between this province, the volcanic Mozambique oblique margin formation and the Gondwana break up are still highly debated. To better understand the composition of the mantle source(s) from which the melts originated and their geodynamic implication from Jurassic times to oceanisation within the Mozambique Channel we studied volcanic and plutonic samples from several drill holes within the South Mozambican Coastal Plain (SMCP) as well as samples from the Movene and the Bumbeni complex areas.

We conducted major, trace elements and radiogenic isotopes $(\mathrm{Sr}, \mathrm{Nd}, \mathrm{Pb})$ analyses as well as ${ }^{40} \mathrm{Ar} /{ }^{39} \mathrm{Ar}$ dating. Our results clearly demonstrate that the SMCP basement is composed of continental lithosphere more or less modified by mantle magmatism as expected in a continental flood basalt setting. Conversely to some previous interpretations no oceanic crust is present within the SMCP which has important implications for the initial Gondwana fit [4].

Our results indicate that a plume-type mantle source, more or less influenced by Sub-Continental Lithospheric Mantle and Upper Depleted ambient Mantle, is involved in the formation of all Karoo-related magmatism episodes in the area. The isotope composition of the African mantle plume is highly comparable to the one of the Afar plume suggesting that the thermal anomaly may have been active for about 200 Ma.

[1] Cox, (1988) In Continental Flood Basalts, Spinger ; [2] Jourdan et al., (2007), J. Petrol., 48 :1043-1077 ; [3] Melluso et al., (2008), J. South Af. Earth Sci. 52:139-151; [4] Thompson et al., (2019) Earth Science Reviews 191:26-56 